\title{
Right extended hemicolectomy, falls and low $\mathrm{B}_{12}$
}

\author{
MA Gosney*
}

Royal Berkshire NHS Foundation Trust, Elderly Care Medicine, London Road, Reading, Berkshire, RG1 5AN, United Kingdom

\begin{abstract}
Background: Falls are common and can be multifactorial.

Settings: An older man presented with a fall and an unremarkable past medical history including a right extended hemicolectomy for a caecal carcinoma and a left hip replacement.

Results: Clinically he had a marked peripheral neuropathy and low serum cobalamin.

Conclusion: The removal of the terminal ilium may remove the site of uptake of vitamin $\mathrm{B}_{12}$ even in the presence of intrinsic factor. Therefore, older patients in whom curative surgery for colonic carcinoma has been undertaken should be monitored for $\mathrm{B}_{12}$ deficiency five years following surgery and until death. $\mathrm{B}_{12}$ may be replaced in the usual fashion in such individuals
\end{abstract}

A 83 - year - old man presented following a fall which resulted in lacerations to the face requiring plastic surgery input. He was otherwise well with an extended hemicolectomy for a caecal carcinoma 18 years earlier and a left elective hip replacement for osteoarthritis, seven years previously. He was a non-drinker on no medication. Clinical examination showed a marked peripheral neuropathy in both hands and feet with signs of diminished pressure, vibration and light touch sensation particularly in the lower limbs bilaterally.

His MCV was $104 \mathrm{fl}$ with a haemoglobin of $102 \mathrm{~g} / \mathrm{dl}$. His serum cobalamin was $<20 \mathrm{pg} / \mathrm{ml}$. Folic acid and iron studies were normal, anti-IF antibody test was negative as was his anti-gastric parietal cell antibody test (GPC).

The neurological signs were likely to be secondary to $\mathrm{B}_{12}$ deficiency in the absence of any other abnormal finding. His vitamin $B_{12}$ dietary income was adequate and his liver function tests were normal. In the absence of any gastric pathology or the use of PPIs or antacids it seemed likely that the vitamin $\mathrm{B}_{12}$ deficiency was not related to intrinsic factor but more likely to be due to removal of the terminal ilium during the extended hemicolectomy. The terminal ilium is the site of uptake of vitamin $B_{12}$ in the presence of intrinsic factor. Having crossed the brush border, the vitamin $\mathrm{B}_{12}$ dissociates from the intrinsic factor and enters the circulation where it binds to transcobalamin II and haptocorrin which are then responsible for the delivery of cobalamin to peripheral tissues and the liver respectively [1-3].

It must be remembered when taking a history from an older patient that surgery even twenty years previously may have unexpected late complications such as almost unrecordable $\mathrm{B}_{12}$ levels resulting in a marked peripheral neuropathy and falls [4]. Treatment was commenced with hydroxycobalamin daily for five days and folic acid. Six months after commencing therapy his peripheral neuropathy was reduced but not fully resolved. He had however had no further falls. Although bacterial overgrowth can also cause low $B_{12}$ post hemicolectomy, the patient denied any diarrhoea and there was no biochemical evidence of malabsorption [5]. The delay in manifestation of $B_{12}$ deficiency is due to the large amounts of $B_{12}$ stored in the liver and therefore any reduction in vitamin $B_{12}$ for whatever mechanism may take five to ten years to manifest clinically.

\section{Learning point for clinicians}

- Falls in the presence of neurological signs may reflect $\mathrm{B}_{12}$ deficiency.

- Previous colonic surgery may remove the terminal ilium - the site of $\mathrm{B}_{12}$ absorption.

- Treatment of $\mathrm{B}_{12}$ deficiency may improve but not ameliorate symptoms and this may be dependent on how long the deficiency has remained undetected.

\section{Conflicts of interest}

None declared.

\section{References}

1. Shipton MJ, Thachil J (2015) Vitamin $\mathrm{B}_{12}$ deficiency - A 21st century perspective. Clin Med (Lond) 15: 145-150. [Crossref]

2. Dali-Youcef N, Andrès E (2009) An update on cobalamin deficiency in adults. QJM 102: 17-28. [Crossref]

3. Nielsen MJ, Rasmussen MR, Andersen CB, Nexo E, Moestrup SK (2012) Vitamin B transport from food to the body's cells--a sophisticated, multistep pathway. Nat Rev Gastroenterol Hepatol 9: 345-354. [Crossref]

Correspondence to: MA Gosney, Royal Berkshire NHS Foundation Trust, Elderly Care Medicine, London Road, Reading, Berkshire, RG1 5AN, United Kingdom, Tel. 0118-322-5474; Fax: 0118-322-6544; E-mail: m.a.gosney@reading.ac.uk

Received: October 04, 2017; Accepted: October 18, 2017; Published: October 20, 2017 
Gosney MA (2017) Right extended hemicolectomy, falls and low $\mathrm{B}_{12}$

4. Andrès E, Loukili NH, Noel E, Kaltenbach G, Abdelgheni MB, et al. (2004) Vitamin $\mathrm{B}_{12}$ (cobalamin) deficiency in elderly patients. CMAJ 171: 251-259. [Crossref]
5. Elphick DA, Chew TS, Higham SE, Bird N, Ahmad A, Sanders DS (2005) Small bowel bacterial overgrowth in symptomatic older people: can it be diagnosed earlier? Gerontology 51: 396-401. [Crossref]

Copyright: (C2017 Gosney MA. This is an open-access article distributed under the terms of the Creative Commons Attribution License, which permits unrestricted use, distribution, and reproduction in any medium, provided the original author and source are credited. 